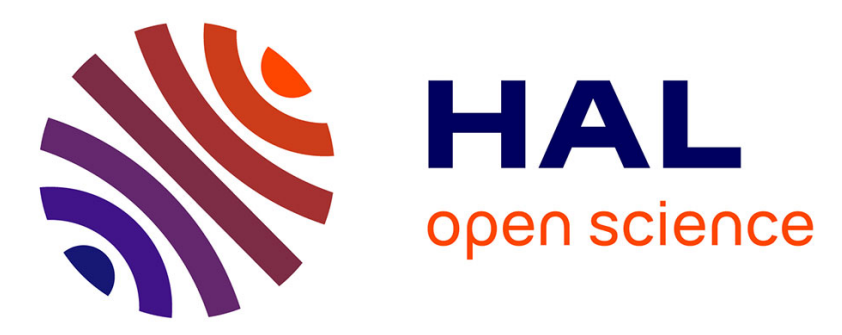

\title{
Pleistocene cold climate groundwater silicification, Jbel Ghassoul region, Missour Basin, Morocco
}

\author{
Médard Thiry, Milnes Antony, Mohamed Ben Brahim
}

\section{To cite this version:}

Médard Thiry, Milnes Antony, Mohamed Ben Brahim. Pleistocene cold climate groundwater silicification, Jbel Ghassoul region, Missour Basin, Morocco. Journal of the Geological Society, 2015, 10.1144/0016-76492014-033 . hal-01236657

\section{HAL Id: hal-01236657}

https://hal-mines-paristech.archives-ouvertes.fr/hal-01236657

Submitted on 2 Dec 2015

HAL is a multi-disciplinary open access archive for the deposit and dissemination of scientific research documents, whether they are published or not. The documents may come from teaching and research institutions in France or abroad, or from public or private research centers.
L'archive ouverte pluridisciplinaire HAL, est destinée au dépôt et à la diffusion de documents scientifiques de niveau recherche, publiés ou non, émanant des établissements d'enseignement et de recherche français ou étrangers, des laboratoires publics ou privés. 


\section{Pleistocene cold climate groundwater silicification, Jbe Ghassoul region, Missour Basin, Morocco}

Médard Thiry ${ }^{1}$, Anthony Milnes ${ }^{2}$, Mohamed Ben Brahim ${ }^{3}$

Géosciences, Mines-Paris-Tech, 35 rue St Honoré, 77305 Fontainebleau, France, medard.thiry@mines-paristech.fr

Department of Geology and Geophysics, The University of Adelaide, South Australia 5005.

${ }^{3}$ University Mohammed Premier, BP 457, 60000 Oujda, Morocco

\section{Abstract}

Surficial silicifications have been long considered to be indicative of warm and dry climates. Here we describe various forms of supergene silicification in a Miocene lacustrine sequence in the Missour Basin near Jbel Ghassoul (Morocco) in a landscape with accentuated relief. The silicification is almost exclusively limited to a 10 - $40 \mathrm{~m}$ wide zone from the edges of scarp and mesa landforms. This distribution is interpreted to record the locations where groundwaters which produced the silicification discharged from a higher level paleolandscape.

The main component of the silica was imported late and significantly post-dates the deposition of the sediments. This implies that significant volumes of silica-bearing solutions flowed through these formations in response to an hydraulic gradient generated by relief. Silicification thus occurred only after uplift and incision of the sedimentary fill of the Missour Basin. The zones of silicification of the Jbel Ghassoul sequence can be linked geomorphically to remnants of high level pediments that have been dated in the literatures as early to middle Pleistocene and interpreted to have been formed during cold climates. Low temperatures in outcrops near the discharge zones during cold periods is considered to be a key factor in silica precipitation from groundwaters.

Keywords : silicification, petrography, groundwater, cold climate, Morocco, Pleistocene,
Silicification in sediments that have not been deeply buried has long been considered to be synsedimentary and indicative of warm and dry climates. This partly resulted from the fact that the early descriptions of silcretes in Australia and Africa, where siliceous pans armour the landscapes (Passarge, 1904; Lamplugh, 1907; Woolnough, 1927; Storz, 1928; Frankel and Kent, 1938), connected them to the current climates in these countries. As a consequence, silcretes in ancient (especially Tertiary) sedimentary sequences in other places around the world were also considered to be an indicator of warm and dry paleoclimates. However, we now know that the silicification in landscapes in Australia and Africa is ancient and has nothing to do with the current climates (Thiry et al., 2006).

Questioning of these earlier interpretations started with the distinction between groundwater silcretes, which need groundwater flows to import the silica (Thiry and Milnes, 1991), and pedogenetic silcretes, which are formed in situ in soil and regolith environments and are more closely related to warm and dry climates (Thiry, 1997; 1999). In the Paris Basin some silcretes are clearly related to PlioceneQuaternary landscapes (Thiry et al., 1988) and thus to temperate or cold climates.

Many studies have been devoted to supergene silicifications in sandstones and carbonate rocks, and to siliceous materials including flints and jasperoid materials. However, it has not been usual to examine the association of various types of silicification in sedimentary sequences containing different lithologies. Here we describe various forms of supergene silicification with varied mineralogical and micromorphological features in a relatively young continental lacustrine sequence in a landscape with accentuated relief. These factors constrain an interpretation of the morphology, origin, environment of formation and age of these interesting features.

\section{Geomorphological and paleoclimatic setting}

The Missour Basin is an intra-mountain depression delineated by Atlasic faults (Fig. 1; Beauchamp et al., 1996; Laville et al., 2007) and the uppermost part of the fill consists of middle Miocene (Benammi \& Jaeger, 1995) and younger Cenozoic and Quaternary continental-lacustrine sediments. It was primarily a molasse basin fringing the Atlas Mountain belts and subsided during the Oligo-Miocene. After the Neogene, a generalized compressional tectonic event generated further relief in the Atlas system and deformed the Oligo-Miocene molasse deposits (Beauchamp et al., 1996; Frizon de Lamotte et al., 2009). A compressional tectonics regime has continued through the Quaternary to the present day, as indicated by significant current seismicity (Medina and Cherkaoui, 1991; Sébrier et al., 2006). Detailed analyses of stream morphology provide evidence for the post-Miocene initiation of relief (Babault et al., 2008) and for Late Quaternary tectonism (Choubert, 1946; Raynal, 1961; Martin, 1981; Lefèvre, 1989; Beauchamp et al., 1996; Gomez et al., 1996).

The Missour Basin sediments are now exposed in vast dissected pediments that converge to the Moulouya River (Raynal, 1961; Lefèvre, 1989, 2008) (Fig. 2), the extensive tributaries of which define the current drainage basin. In the west, Jbel Ghassoul peaks at $1439 \mathrm{~m}$ whereas the bed of the Moulouya River to the southeast is at about $1000 \mathrm{~m}$ elevation. In the Missour area the higher level (older) P4-P5 pediments are considered to be early to middle Pleistocene in age (Moulouyen = Pretiglian and Elsterian) based on their association with the Acheulean stone tool industry (Lefèvre, 1989). 


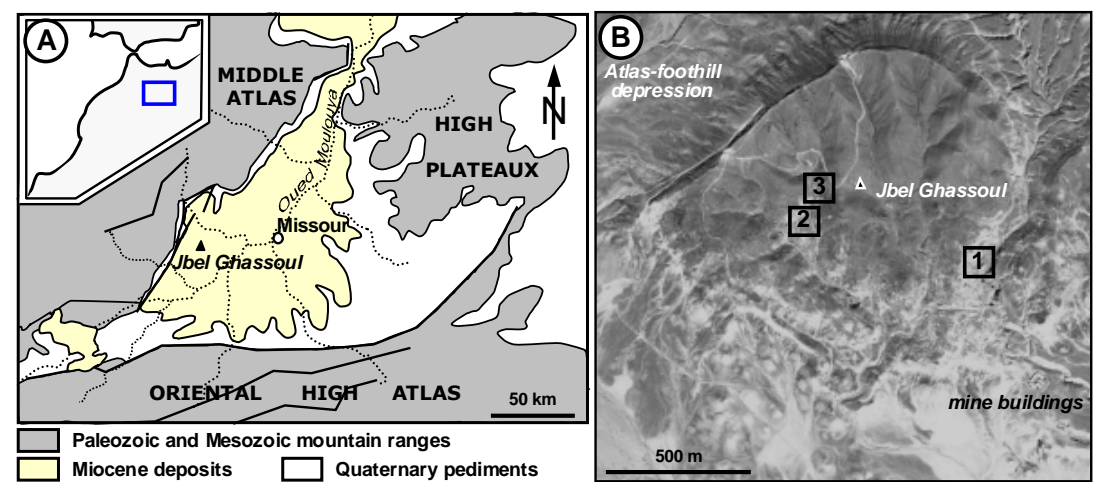

Figure 1- Missour Basin setting. (A) Geologic sketch of the Missour Basin showing the distribution of Miocene and younger sediments. The Moulouya River and its tributaries define the modern drainage basin which is "confined" to the north. (B) Aerial view of the mining site showing the $\mathrm{N}$ scarp and SEsloping and dissected upper surface of the Jbel Ghassoul landform abutting the Moulouya River pediments. Numbers show main sampling sites (see Fig. 3).

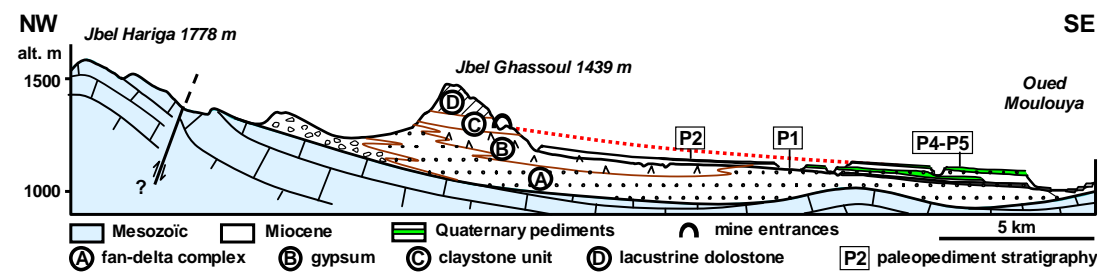

\section{Figure 2 - Cross section of the Missour Basin (Moulouya River valley) showing dissected paleopedinents}

'anchored' to Jbel Ghassoul. P1-P2 late Pleistocene, P4 middle Pleistocene, P5 middle-early 'anchored' to Jbel Ghassoul. P1-P2

The Atlas Mountains were periglacial during Pleistocene cold stages (Dresch and Raynal, 1953; Awad, 1963; Martin, 1981; Couvreur, 1966; Hughes et al., 2004). Glaciers reached as low as $2000 \mathrm{~m}$ in the High Atlas and 2100-2300 m in the Middle Atlas (Awad, 1963; Hughes et al. 2011). Rock glaciers, commonly found in areas of discontinuous permafrost, have also been recognised down to $2100 \mathrm{~m}$ elevation in the Middle Atlas (Awad, 1963). As well as cryonival and ice-wedge structures that are typical of periglacial environments, stratified debris, bedded scree, stone polygons and solifluction features have been described in the Moulouya River basin and bordering areas down to $1300 \mathrm{~m}$ elevation (Raynal et al., 1986)

The regional snowline in the Middle Atlas during the main glacial phases of the Pleistocene is estimated to have been at ca $2800 \mathrm{~m}$ elevation (Awad, 1963). During the late Pleistocene the mean minimum temperature of the coldest month was $0^{\circ} \mathrm{C}$ at ca. $900 \mathrm{~m}$ whereas today it is at ca. $1600 \mathrm{~m}$ (Messerli and Winiger, 1992). The presence of rock glaciers in the Middle Atlas also suggests that temperatures in the Pleistocene cold stages, when they were active, were about $10^{\circ} \mathrm{C}$ lower than today (Hughes et al. 2004). More broadly, in the Mediterranean area, a temperature depression of at least $11^{\circ} \mathrm{C}$ in summer for the coldest Pleistocene cold stage (MIS 12, 420-480,000 years ago) has been suggested (Hughes et al., 2007).

Thus, the extensive Pleistocene pediments in the Missour Basin are interpreted to have formed under cold and dry climatic conditions with intense congelifraction (frost shattering and ice heaving) whereas erosion marked by linear gullies and alluvial terraces occurred during warmer and wetter climates (Lefèvre et al., 1985; Lefèvre, 1989).

\section{The Jbel Ghassoul formation}

The Jbel Ghassoul formation is composed of four main sedimentary units that were deposited in the distal parts of the original molasse basin (Raynal, 1961; Trauth, 1977; Duringer et al., 1995) (Figs 2

(1) A thick, red, fluviatile, silty marl at the base, unconformably overlying Mesozoic bedrock.

(2) A white gypsum-rich unit overlying the red marl and formed mainly of powdery gypsum interspersed with a few clay layers. This unit contains horizons with swallowtail- and fishtailtwinned gypsum crystals that indicate evaporitic lagoonal paleoenvironments.

(3) A claystone unit composed of alternating marl and dolostone layers in which the Ghassoul clay layers are more or less continuous and about 10 to $70 \mathrm{~cm}$ thick. The principal component of the Ghassoul clay is Mg-rich smectite (Li-stevensite) which formed in pre-evaporitic, confined palustrine environments (Trauth, 1977) and is mined in underground galleries accessed from erosional scarps

(4) A dominantly dolomitic uppermost unit with thick, massive dolostone beds that were deposited in lacustrine and palustrine paleoenvironments.

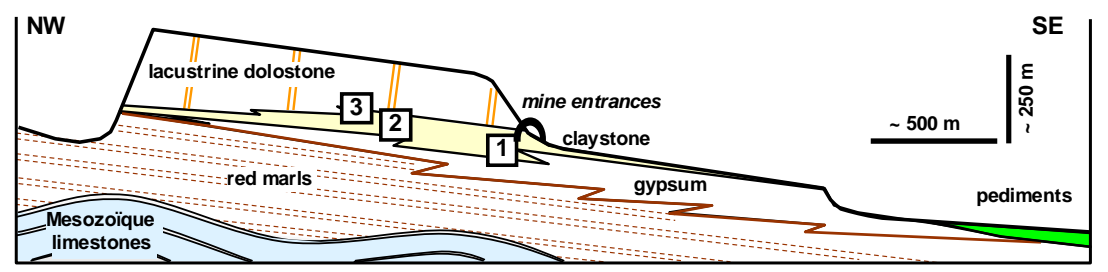

Figure 3 - Schematic section through dissected paleopediment composed of Jbel Ghassoul formation showing location of sampling sites. (1) "gogotte -like silicification within disrupted zone of claystone unit, (2) layered silicifications confined to claystone unit, (3) nodular silicification in overlying dolostone unit.

These sedimentary units show numerous facies changes from the distal parts of the basin towards the foothills of the Middle Atlas Mountains where conglomeratic (colluvial and alluvial) facies prevail (Fig. 2; Duringer et al., 1995; Chahi et al., 1999).

Secondary gypsum occurs in the gypsum unit, as well as in the claystone unit, as fibrous veins, rosettes, and powdery gypsum in vertical fractures and along bedding planes (Duringer et al., 1995). This gypsum may be of recent origin and related to the incision of the Jbel Ghassoul formation. However, it could also be of synsedimentary origin due to remobilisation of gypsum during periods of water table lowerihg, or may have been derived from gypsum lunettes formed around evaporitic depressions.

Silicification is particularly abundant in the claystone unit where it occurs in a variety of structures and morphologies including lenses and irregular metre-sized bodies, as well as nodules and millimetre- to centimetre-wide veins. In places, silicification has been particularly intense and the volume of silica can exceed that of the claystone host. Silicification has also developed above and below the claystone unit, in the upper part of the gypsum unit and in the uppermost dolostone unit where it occurs as nodules and fracture fillings. 
The distribution of silicification in the landscape is shown in Figure 4. It is confined to the edges of outcrops in scarps and valleys cut into the sedimentary sequence, but does not extend for more than 10 to $20 \mathrm{~m}$ into the landforms, as demonstrated by observations in mine galleries. The silicified horizons occur 30-40 $\mathrm{m}$ above current base level defined by the local modern drainage gully network and clearly correlate with the paleopediments of early to middle Pleistocene age (Lefèvre, 1989; Fig. 2).

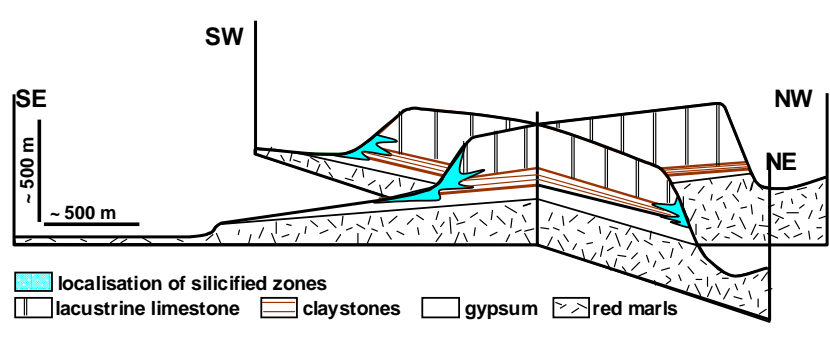

Figure 4 - Disposition of silicified zones with regard to current relief and morphology of the Jbel Ghassoul formation.

Of particular note also is that the sedimentary layering, particularly in the claystone unit, is completely disrupted for some 10 to $20 \mathrm{~m}$ inwards from the margins of scarps. The disintegration is marked by sub-vertical dislocations more or less parallel to the edges of mesas, collapse structures and brecciation. These zones of disruption are specific to outcrops of the claystone unit and do not occur in the underlying and thus more recently incised red marl.

These dislocation structures may relate to the general processes of breakup of the pediments and scarp retreat. They could, for example, be caused by collapse due to lateral wasting of the slopes and even near-surface diss blution of the underlying gypsum unit. On the other hand, many aspects of these dislocations are comparable to cryogenic structures, such as frost shattering and ice wedging, further deformed by differential frost heaving. Thus, they are considered to be related to periglacial structures which have been observed regionally (Raynal, 1961) and thus connect to the Pleistocene cold climates considered to be responsible for the development of the piedmont landscape (Lefèvre et al., 1985; Lefèvre, 1989, 2008). Periglacial structures have been observed as low as $1300 \mathrm{~m}$ elevation approaching the height of Jbel Ghassoul (Couvreur, 1966, 1988; Raynal et al., 1986).

The extent of silicification in the upper parts of the Jbel Ghassoul formation is indicated by the fact that the pediments downslope, especially in the mined areas, are completely covered by prehistoric artefacts and chips of siliceous material. Evidence of an established prehistoric industry for the production of stone tools is also widespread over the palaeopediments between Jbel Ghassoul and the Moulouya River.

\section{Description of the silicified facies}

Three sites representative of the silicified facies have been sampled (Fig. 3)

1) 'Gogotte'-like silicified masses, centimetres to many decimetres in size, are rounded, generally light-coloured with a rough aspect, and contain lustrous and dark coloured zones and nodules in places. They are confined to the disrupted and fragmented zones of the claystone unit and are well exposed at the entrance to the mine galleries.

2) Layered silicifications with shiny fracture surfaces and a brittle cortex are closely related to the Ghassoul clay layers. They were sampled in the mine area in erosional channels behind outcrops of the gypsum unit and display sedimentary-like layering.
3) Nodular silicified zones, light or dark in colour and centimetres to decimetres in size, with a flinty fracture, are arranged in layers or aligned along fractures in dolostone beds. They were sampled in the uppermost part of the claystone unit and in the base of the overlying lacustrine dolostone unit.

\section{‘Gogotte’ silicifications}

'Gogotte'-like silicified masses occur near the base of the claystone unit in zones where the primary stratigraphy has been significantly disturbed and disrupted by abundant gypsum along subvertical fractures more or less parallel to the margins of the scarp or mesa landforms (Fig. 5). They are well exposed at the entrance to mine galleries but persist only for some tens of metres into the body of the landform.

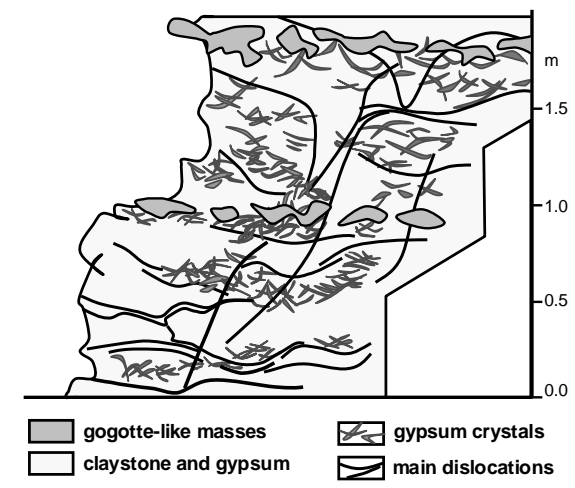

Figure 5 - 'Gogotte'-like silicified masses within the disrupted and dist
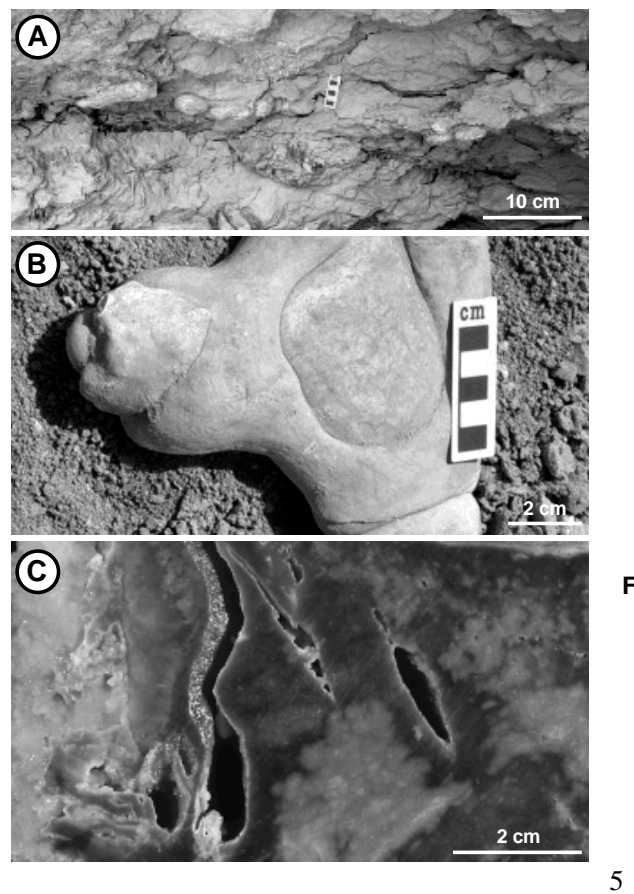

Figure 6 - 'Gogotte'-like silicified zones within disrupted and disturbed zones of the claystone unit. (A) Centimetric gogottes' within gypsum bearing 'maris. (B) 'Gogotte' showing of accretionary growth). (C) Section of a 'gogotte' showing spindle-shaped voids resulting from dissolution of gypsum crystals. 
Although sedimentary structures can be wholly disrupted in these outcrops, the gogottes are nevertheless aligned along superimposed horizontal planes cross cutting the disruption features (Fig. 6A). The gogottes always have a regular rounded shape and often have superposed folds or envelopes, each covering an earlier one (Fig. 6B). These envelopes indicate that the silicification was a process of accretion, by addition of centimetre-thick layers or zones. Gypsum in these outcrop and near-outcrop zones is mostly formed of large secondary crystals whose relationship with the silicification is complicated. Some gypsum crystals have been silicified: others have been incorporated into the gogotte structures (Fig. 6C) and thus clearly pre-date the silicification. However, gypsum is mobile in the outcrop zone and numerous gypsum crystals and rosettes encase the gogottes and post-date the silicification.

\section{Layered silicifications in the claystones}

These silicifications are closely related to the smectitic Ghassoul clay layers. They occur as irregular and superimposed metre-sized masses, encased by gypseous marls and greenish clays (Figs 7, 8). The silicified masses almost always display layering inherited from the claystones (Fig. 8A) but consist of decimetric masses enwrapped in laminae composed of brown clays and can be arranged in specific layers (Fig. 8B). Some silicified horizons are formed of corrugated laminae that resemble flexible deformation of clay layers. Others contain vacuoles with centimetre-sized tubular or irregularly-shaped hollows, more or less interconnected, that clearly result from dissolution.

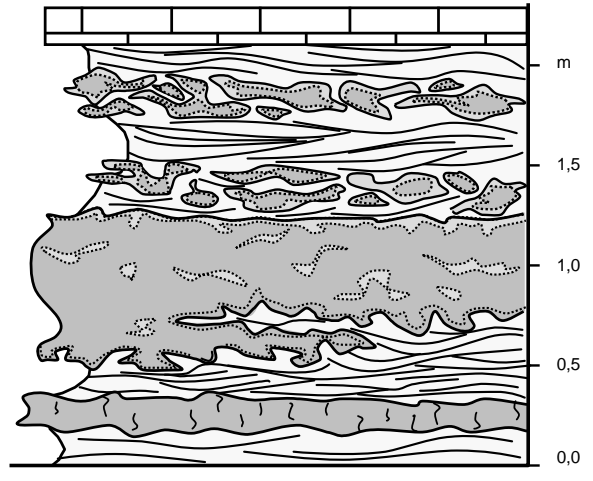

$\square$ dolostone $\mathrm{chalky} \mathrm{dolomite} \mathrm{and} \mathrm{brownish} \mathrm{clays}$ $\square$ layered flint-like silicifications $\square$ scoria-like cortex
Figure 7- Layered silicified bodies in close relationship with Ghassoul clay layers.
Orig inal layering of the deposits are mostly preserved.
The layered silicifications are generally of dark colour without visible grains, and have a lustrous conchoidal fracture (Fig. 8C). They contain thin laminae, traces of roots and burrows, and a pseudobreccia structure related to desiccation. Joints and pores are often coated with bluish chalcedony of pearly aspect. The silicified masses often have a brittle cortex that is more or less powdery.

These silicifications are particularly plentiful near the outcrop at the scarp face but disappear within of metres of the entrances to the mining galleries. Waste rock heaps at the gallery entrances contain only sparse silcrete fragments.
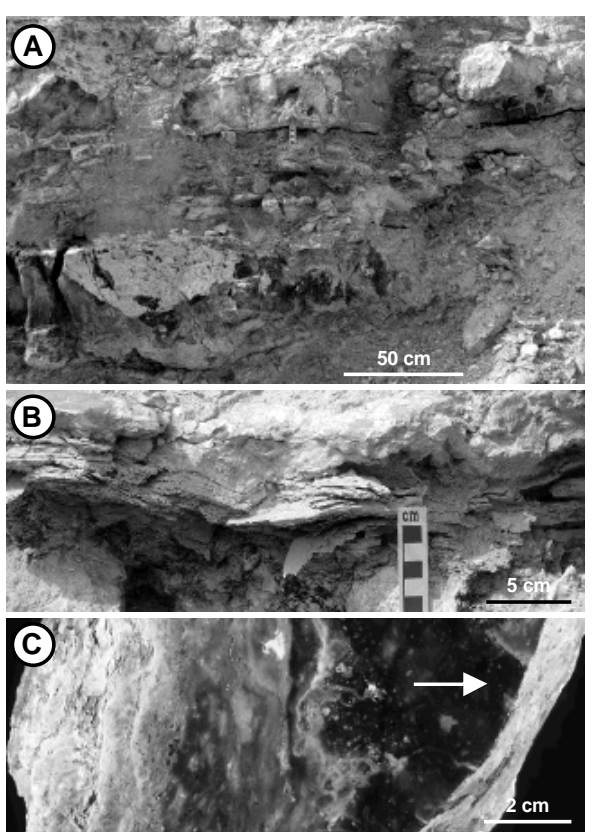

Figure 8 - Layered silicified masses in close relationship with Ghassoul clay layers. (B) Onion-like, brittle, silicified laminae around silicified zones. (C) Silicified mass with dark shiny core speckled with beige granules; the lower part is irregular and has a dull lustre; the upper part has a porcellanite lustre transitioning to brittle silica.

\section{Silicified nodules in the dolostones}

The lacustrine dolostones in the upper part of the Jbel Ghassoul formation contain silicified nodules with a splintery to conchoidal fracture and a black patina. These are plentiful at the base of the dolostone unit and less common towards the top. Their size varies from millimetre-sized chips to decimetre-sized masses. They are amoeboid in shape, from $2-10 \mathrm{~cm}$ in thickness, and appear to be aligned on sedimentary structures stretching out along the stratification (Fig. 9A). Thinner, millimetrethick slabs of silica representing silica-infilled veins and fractures sometimes form a network interconnecting the amoeboid masses (Fig. 9B). These silicifications are generally light coloured, beige, grey or bluish, and more or less translucent (Fig. 9C). Sometimes they have a dull fracture and contain some residual carbonate in the form of nodules or scattered micrite in the siliceous matrix 


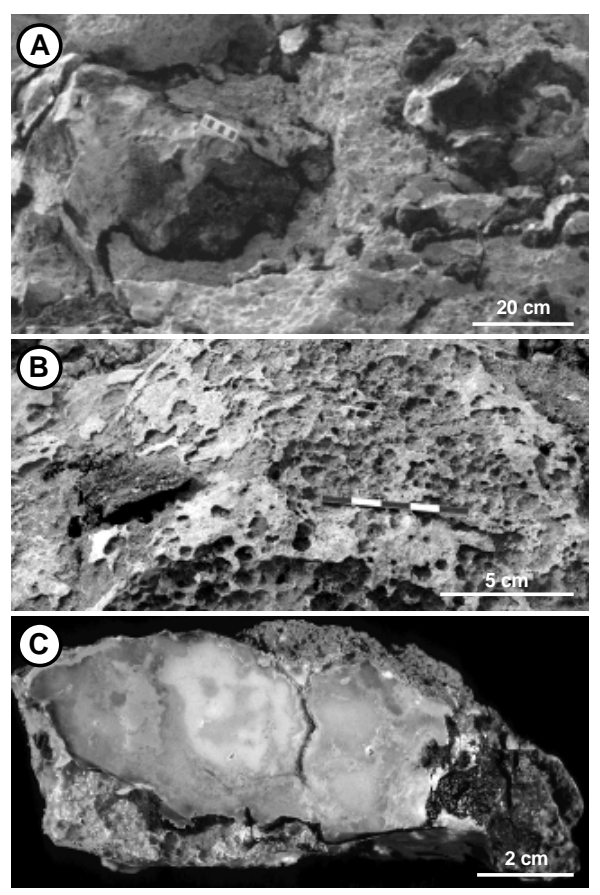

Figure 9 - Nodular silicifications in the lacustrine dolostone unit. (A) Flint-like nodules with a black patina. Nole the irregular shape of the more or less continuous silicified jints. (B) Silica veneers along a fracture. (C) Silicified nodule with possible dehydration cracks.

\section{Mineralogy of the silicified materials}

All the sampled silicified materials were analysed by XRD. Although silica minerals are dominant, there are also traces of dolomite and sometimes gypsum. In summary:

1) Quartz is the main mineral in all the silicified materials. It has sharp and intense diffraction lines (Fig. 10A) indicating good crystallinity. All the gogottes have this type of quartz. On the other hand, the layered silicifications in the claystones have broadened diffraction lines indicating quartz with numerous lattice defects and a low degree of crystallinity (Fig. 10B).

2) Moganite is a hydrated silica variety (Flörke et al., 1984) and often accompanies quartz with broadened diffraction lines in the layered silicifications. It is especially well developed in the brittle silicified laminae in close association with the smectitic clay layers.

3) Opal-CT also occurs in the shiny and brittle silicified laminae associated with the Ghassoul clay layers (Fig. 10C). Petrographic observations show that these materials contain botryoidal lussatite in pore spaces.

4) A weak diffraction band sometimes occurs near $4.45 \AA$ (Fig. 10C). This diffraction band appears in most of the silicified samples that contain opal-CT. It is most probably related to the (110) and (020) reflections of residual clay mineral sheets within the opal-CT. This may point to the destruction of octahedral layers in the original clay minerals, and transformation of the tetrahedral layers into tridymite or cristobalite tetrahedral layers, without total destruction of the basic clay structure (Rayot et al., 1992).
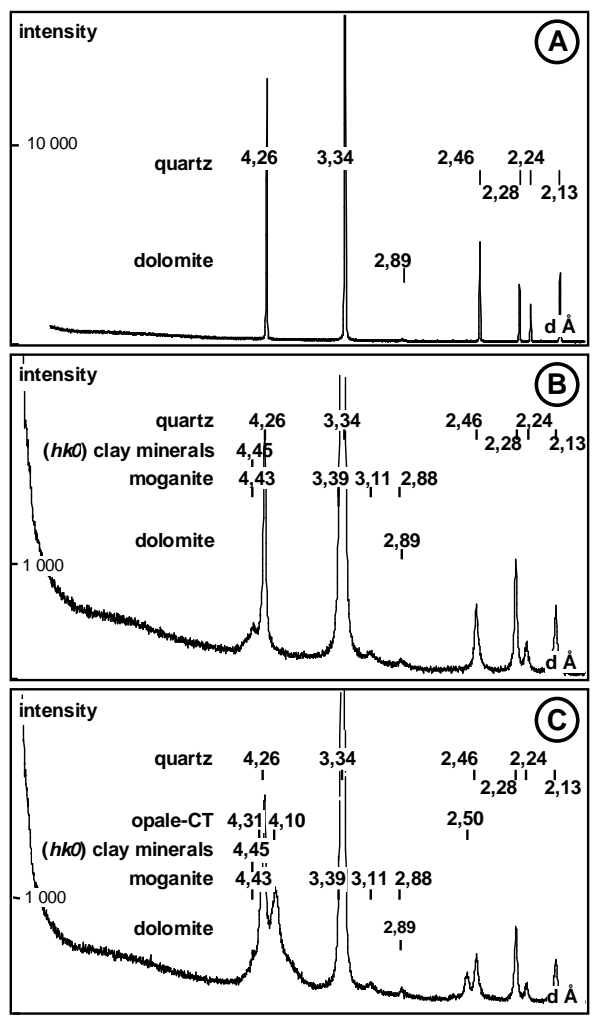

Figure 10 - X-Ray Diffraction diagrams of the quartz in a gogote (A) Well crystallized brittle silicified laminae of the layered silicification. (C) Opal-CT in a flint-like layer within the layered silicification. Note the diffraction band near $4.45 \AA$ A most probably inherited from alteration of primary clay minerals. This band also appears in $B$ where it is relatively intense in relation to the moganite pattern.

\section{Petrography of the silicified materials}

Thin section studies differentiate the three types of silicified facies in the Jbel Ghassoul formation and provide details of their interrelationships. These observations also provide the basis for establishing a temporal sequence of silica deposition, transformation and recrystallization.

\section{The gogotte structures}

The petrofabric of the gogottes is quite monotonous and they are mostly composed of very fine microcrystalline quartz. The only inclusions are small rhombs of dolomite $2-30 \mu \mathrm{m}$ in diameter (Fig. 11A). The microcrystalline quartz matrix has two distinct fabrics: (1) one in which there is no observable remnant of the primary (pre-silicified) material, either in terms of the granularity of the microquartz, or any impurity inclusions; (2) and the second in which there is an inherited organisation indicated by micronodular structures perceptible by their darkness due to micro-inclusions and quartz grain size variations.

Some rare structures appear to be silicified shell fragments. 

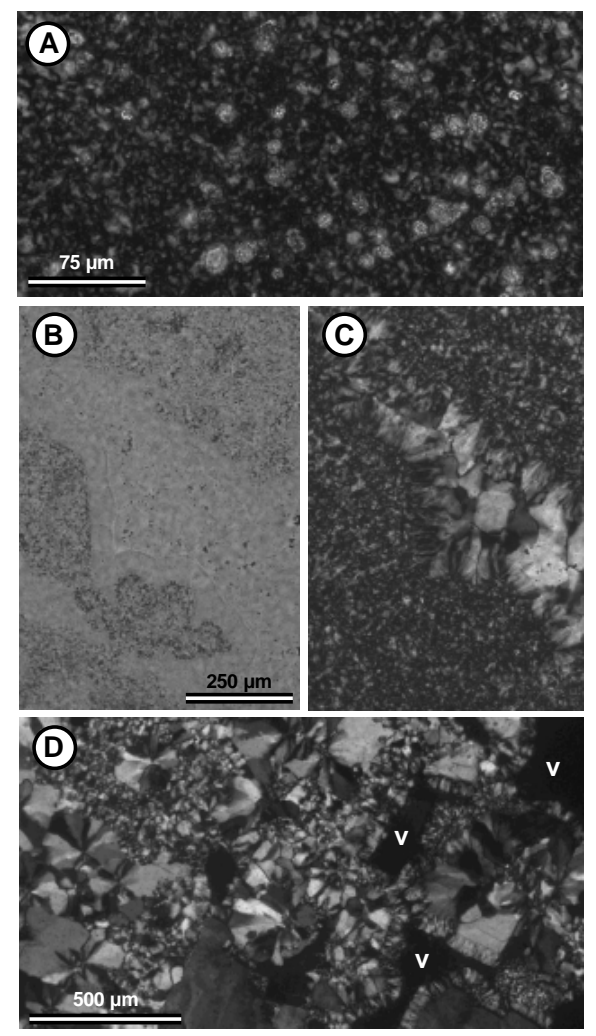

Figure 11 - Gogotte silicifications. (A) Microcrystalline quartz with small euhedral dolomite crystals; crossed polars. (B \& C) Microcrystalline quartz matrix and pore filing of botryoidal silica composed of palisade quartz overlain by sub-euhedral quartz; B analysed light, C crossed polars. (D) Microcrystalline matrix and petaloid quartz, succeeded by a fringe of chalcedony owards the centres of the pores (v). Crosse polars.

\section{Palisade/mosaic quartz sequences}

"Classical" crystallization sequences (Fig. 11B \& 11C) occur in pores and voids in the gogottes. These start as coatings on the walls and are botryoidal deposits formed of fan-like, elongated palisade quartz that obviously result from the recrystallization of chalcedony, or even opal. The palisade quartz, which is either length-fast or length-slow, and differs from one sample to another, is succeeded by subeuhedral mosaic quartz in the centres of the pores or voids.

\section{Petaloid quartz}

The occurrence of petaloid (or petal-like) quartz (Arbey, 1980) is one of the characteristics of the matrix of the gogotte silicifications. These are large quartz crystals $100-250 \mu \mathrm{m}$ in length that have developed in a radial fashion likened to the spreading of a flower (Fig. 11D). The central seeding points are often small, elongated quartz crystals more or less oblique to the beams of the crystallaria (Fig. 11D and 12B). The enlargement of these small crystals was hindered by the growth of the crystals along the beams of the crystallaria. The terminations of the large crystals are often euhedral and display growth lines. Some of these crystals are length-slow and display a "cubic" habit (Fig. 12B).

\section{Quartz with "pseudo-cubic" habit}

Pseudo-cubic quartz crystals are large, display zones and growth facets with angles close to $90^{\circ}$ are length-slow, and have the c-axis oriented along the diagonals of the cubes (McBride \& Folk, 1977;

Arbey, 1980). These crystals are remarkable because of the crenulated growth zones that are separated by thin films that appear brownish in polarized light and hollowed out in reflected light (Fig. 12). It is difficult to determine if these films correspond to solid or fluid inclusions, or to amorphous silica. Pseudo-cubic quartz habits are interpreted to be symptomatic of sulphate-rich environments (Arbey, 1980).

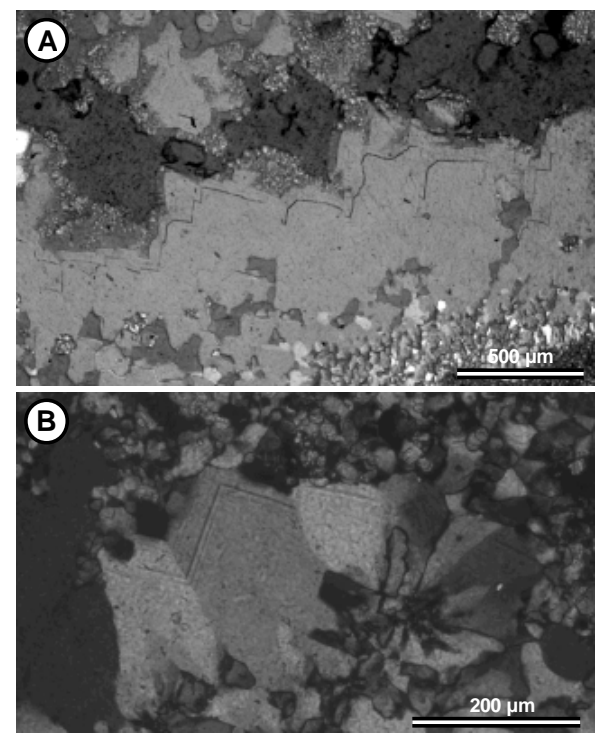

Figure 12 - "Gogotte" silicifications. (A) Large pseudo-cubic quartz crystals wh common from a palisade quartz base. Crossed polars. (B) Pseudo-cubic terminations of petaloid quartz. Crossed polars.

Pseudo-cubic quartz crystals can be millimetre-sized in pores that may have resulted from dissolution of gypsum crystals (Fig. 12A). A question arises as to the origin of these large quartz crystal domains of monocrystalline appearance. They develop from the uneven edge of a pore space on which the first silica precipitates are palisadic quartz. From this, some crystals of specific orientation develop to the detriment of other orientations. Thus, the large domains that show a single orientation and are of monocrystalline appearance under the optical microscope are in fact polycrystalline domains, resulting from the juxtaposition of several crystals of the same orientation. It is possible that the development of this particular orientation results from the influence of foreign ions, in this particular case sulphate, favouring the preferential development of particular crystal faces (Merino et al., 1994; Bosbach \& Hochella, 1996; Takahashi et al., 2004).

\section{The layered silicifications}

The layered silicifications are characterized by an abundance of opal-CT and moganite. Weak diffraction lines near $4.45 \AA$, and sometimes $2.50 \AA$, point to silica tetrahedra in the opal-CT inherited from tetrahedra in pre-existing clay minerals (Rayot et al., 1992). The powdery cortices of these silicified horizons are distinguished by the absence of opal-CT and other paragenetic varieties of silica. This suggests that these forms of silica were unstable and did not survive dissolution or recrystallization.

The layered silicifications also contain remnants of primary sedimentary structures in places, for example sedimentary layering and siliceous microorganism fossils. In addition, zones of microcrystalline quartz have developed from recrystallisation of the opal facies. 


\section{Preserved sedimentary structures}

The sedimentary layering preserved in these silicifications is marked by alternations of submillimetric laminae of brown opal (completely isotropic under crossed polars) and lighter-coloure laminae that show a weak length-slow birefringence (Fig. 13A \& 13B). The birefringence in the lighter coloured laminae is probably due to relict precursor clay minerals, as highlighted by XRD. However, it's not clear if the birefringent laminae are exclusively formed of smectite or also contain some opal. In fact, thin sections of these materials can be cut without the need for artificial hardening because it appears that opal has 'impregnated' the clays. Other samples have laminae with lumpy brown opal and contain numerous micro-pores filled with concretionary opal.

Some samples contain siliceous micro-organisms, most probably radiolarians (Fig. 13C). Others have millimetre-thick laminae composed completely of siliceous tests cemented by brown opal. In mos samples, however, the siliceous tests are scattered in a matrix of opal or microcrystalline quartz. In the microcrystalline quartz facies, the tests have been recrystallized to microquartz and can be recognized only by a very weak difference in refringence (perhaps due to remnant opal) when defocusing the microscope.

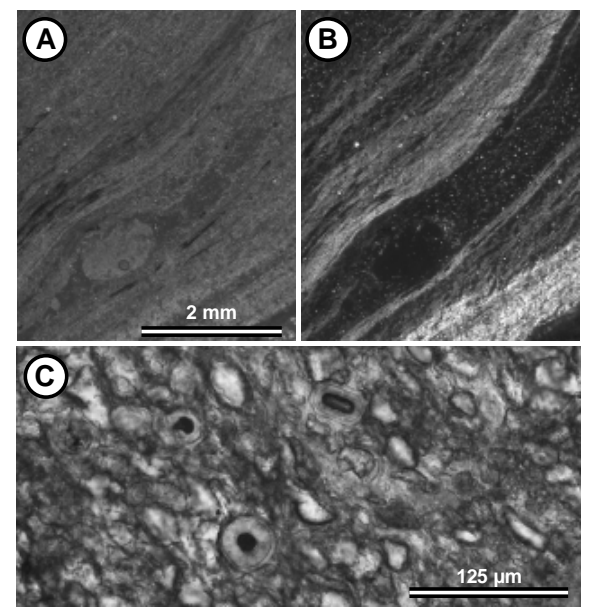

Figure 13 - Layered silicifications. (A \& B). The lighter laminae contain clay minerals; the dark laminae are formed of opal (opal-CT by DRX). $A=$ analysed light, $B=$ crossed polars. C) Siliceous tests (possible radiolarians) embedded in opal; crossed polars.

\section{Silica-filled cracks}

As distinct from the gogotte silicifications, cracks millimetres to many centimetres in length have developed in the horizons of layered silicifications (Fig. 13). Nodular and pseudo-breciated facies composed of opal often contain hair-like and curved cracks infilled with diverse varieties of silica. These structures evoke clays that have undergone shrinkage, bioturbation and/or pedogenesis (Fig. 14A). Frequently, the cracks are cross-cutting and successive phases of development and infilling can be observed (Fig. 14B). In an initial analysis, the geometry and the infillings of the cracks suggest that they relate to an expanding system. However, it may be that shrinkage due to dehydration of a clayey matrix could explain the arrangements.

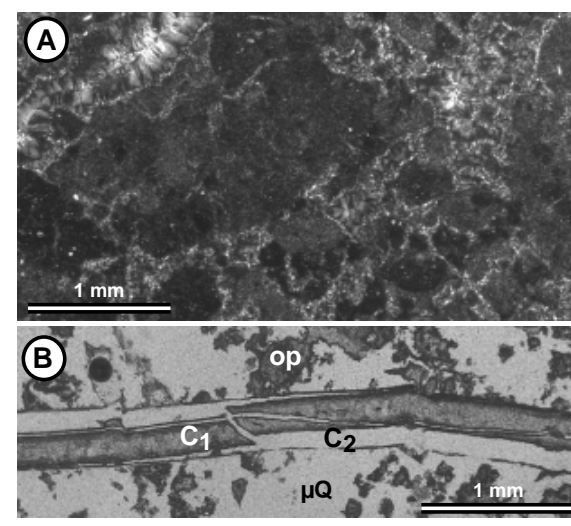

Figure 14 - Layered silicifications. (A) Micronodular silicification in which the nodules are ormed of opal containing a scatter of very ine microcrystalline quartz. The cracks are infilled with diverse quartz varieties. Crossed polars. (B) Silica-infilled fracture which shows several stages of fracture development and (n) (uQ) microcrystalline quart; analysed light.

\section{Microcrystalline quartz matrix}

In addition to opal, it is the microcrystalline quartz matrix that characterizes the layered

silicifications. Domains of microcrystalline quartz are homogeneous and show no particular structure. On the other hand, the transition between the opal and the microcrystalline quartz matrices is always irregular and indented, and there are often remnants of opal within the microcrystalline quartz (Fig. 15A) "Primary" structures such as the laminations and the cracks control the distribution of opal and microcrystalline quartz. In some places there is opal in and around the cracks (Fig. 15B); in other places varieties of quartz occur within the cracks with microcrystalline quartz surrounding them.

The spatial relations between opal and microcrystalline quartz, as well as the "ghosts" of siliceous microfossils within the microcrystalline quartz domains, indicate that microcrystalline quartz ha developed as a result of recrystallization of opal.

\section{Silica deposits in pores and joints}

The earliest silica precipitates in pores and voids are generally mammillary-structured and microlaminated varieties of opal or fibrous silica with low birefringence (pseudo-chalcedonite). These are succeeded by micro-laminated chalcedony and finally chalcedony sheaves, or even quartz, in the centres of voids, to complete the sequence. In places, ribbons of opal and pseudo-chalcedonite are interrupted by "better crystallized" silica, especially chessboard- or zebraic-chalcedonite with closely juxtaposed lengthslow and length-fast fibres (Fig. 16A \& 16B). The contact between the two silica varieties is irregular and cuts across the ribbons of primary silica deposits, thus indicating recrystallization of the opal/pseudochalcedonite to chessboard-chalcedonite.

The largest pores or voids, more than a millimetre in diameter, often result from the dissolution of gypsum. These structures contain thick concretionary silica deposits with successive crosscutting sequences. They are often composed of lutecite, a length-slow fibrous silica variety with characteristic pseudo-rhombohedral herringbone chevron-patterns (Fig. 16C). 

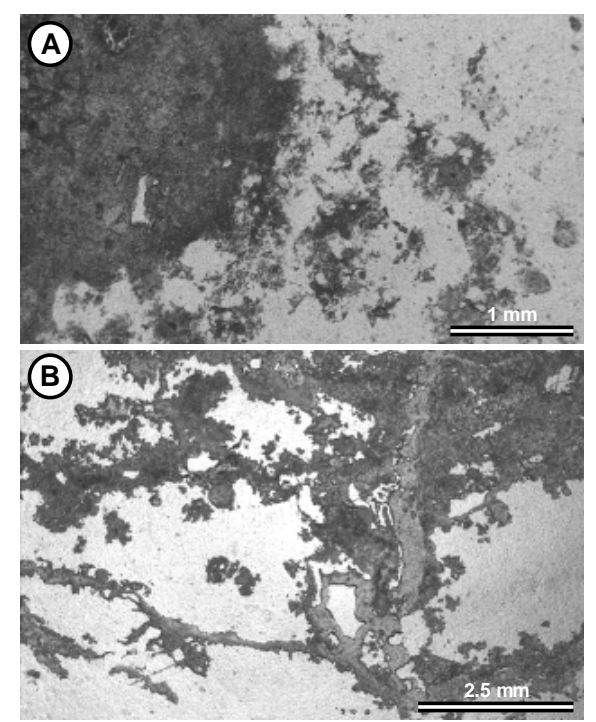

Figure 15 - Layered silicifications. The dark domains are opal (opal-CT by XRD) and the light domains microcrystalline quartz; quarz tends to blur micronizar of opal to inherited from the former claystones. (B) Recrystallization of opal to microquart does not affect opal deposits infilling the cracks.

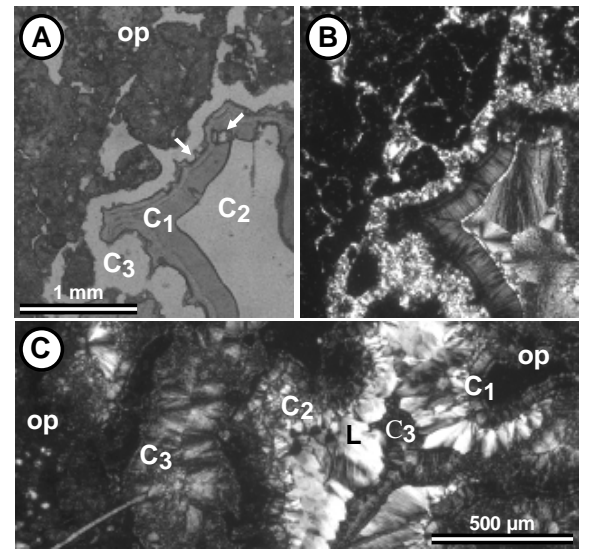

Figure 16 - Layered silicifications. (A \& B) Silica deposits in a pore; (C1) ribboned pseudothe central part of the pore, (C3) twisted chalcedonite derived from recrystallization of pseudo-chalcedonite which cuts across the ribbons (arrow), (op) opal matrix; $A=$ =analysed light, $B=c r o s s e d$ polars. (C) Successive silic deposits in a large void; (C1) pseudolutecite with characteristic chevron-pattern, (C3) chalcedonite, (op) opal and microcrystalline quartz matrix; crossed polars.

\section{Nodular silicifications}

The silicified zones within with the dolostones never contain opal. They are exclusively composed of diverse varieties of quartz: fibrous quartz including pseudo-chalcedonite, chalcedonite and quartzine, microcrystalline quartz, isomorphic amoeboid quartz, and petaloid quartz. Two types of silicification coexist: silica precipitates in voids, and epigenetic replacements of the original dolomitic matrix with preservation of primary sedimentary structures.

\section{Silicification of the original dolomitic matrix}

Epigenetic silicification of the original dolostone matrix has produced mainly microcrystalline quartz and small amoeboid or flame-like quartz crystals, but also small tangled silica spherulites. Many of the petrographic fabrics are comparable to those described in other silicified carbonate rocks (Thiry and Ben Brahim, 1997; Thiry and Ribet, 1999).

Microcrystalline and fine amoeboid quartz fabrics are the most common. The crystal size of the quartz seems to have been controlled by the primary carbonate fabric and its structures are preserved (Fig. $17 \mathrm{~A} \& 17 \mathrm{~B})$

Chalcedonite spherulites about $50 \mu \mathrm{m}$ in diameter also replace the primary dolomitic matrix (Fig. 17C). Their growth is centrifugal, towards the outside, and the outer shells are less refringent. They may coalesce and form interpenetrated contacts or rectilinear sutures with triple junction points. Micrite inclusions can remain within the spherulites.

Isometric and petaloid quartz, about $50 \mu \mathrm{m}$ in diameter, also develop within the micrite Sometimes these forms have micrite inclusions in zones that follow the outlines of the quartz. The micrite zones retain spherulitic features and appear to result from the recrystallization of former chalcedonite spherulites.

In places, subeuhedral quartz develops within the micrite. These crystals display successive growth zones formed alternatively of aureoles of limpid quartz and aureoles of quartz with micrite inclusions, similar to those described elsewhere in carbonate rocks (Thiry and Ribet, 1999).
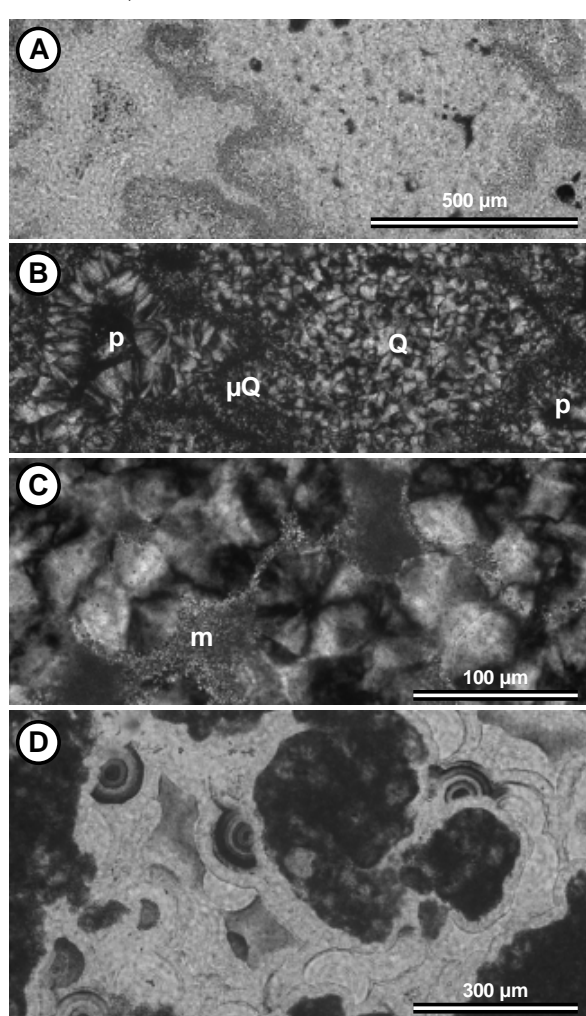

Figure 17 - Nodular silicifications. (A \& B) Silica varieties differentiated according to their position in relation to pores; $(p)$ pore, $(\mu \mathrm{Q})$
opal and microquartz around pores, $(\mathrm{Q})$ isometric quartz resulting from silicification of original carbonate matrix; $A=$ analysed light, B=crossed polars. (C) Chalcedonite spherulites within micritic matrix; $(\mathrm{m})$ dolomicrite. Analysed light. (D) Thick silica deposits and concretions in a pore. Silica deposits show successive overlapping stages. The darkest spherulites are formed of pseudo-chalcedonite which is overlain by developed during the final stage of quartzine replaced by microquartz and larger has bee crystals clouded by micro-inclusions of calcite. Analysed light. 


\section{Silica deposits in pores}

Silica deposits in pores and cracks in the dolostones are not basically different from those found in the layered silicifications. However, they are distinguished by the absence of opal, although the chessboard- or zebraic-chalcedonite that occurs possibly results from the recrystallization of opal, as observed in the layered silicifications. As a general rule, the precipitation sequences evolve from poorly crystallised towards better crystallized varieties of silica, generally chalcedonite or quartzine, and more rarely isometric quartz crystals. The deposits are sometimes very thick, reaching 200 - $400 \mu \mathrm{m}$ (Fig. 17D).

The silica matrix appears mostly to be composed of microcrystalline quartz and chalcedonite. However, defocusing the microscope highlights small "ghosts" of juxtaposed concretionary features. Importantly, there is a systematic connection between silicification and zones of high porosity that may be partly or totally infilled with silica deposits. The textures suggest a concomitant dissolution and silicification process that preserves the primary carbonate sedimentary structures.

\section{Interpretation of micromorphological features}

\section{The gogotte silicifications}

The arrangement of the gogotte silicifications that crosscut the disruption and collapse structures indicates that they formed after the disintegration of the rocks in outcrop, and thus post-date the incision of the Moulouya Valley and exposure of the Jbel Ghassoul formation.

The development of tightly cemented lenses, with very low residual porosity, is achieved by concentric growth and develops by precipitation of successive centimetric layers of silica, which are in sharp contact with the host rock. There is apparently no particular structure that promoted silica precipitation in the centre of the gogottes. The source of silica is external and has to be imported in solution, indicating considerable water flows through these zones. These water flows are not conceivable under the current dry climate of the region and thus must relate to wetter periods in the past. The horizontal arrangement of the gogottes suggests that they developed in relation to a water table.

\section{The layered silicifications}

The layered silicifications are confined to the smectitic clay layers of the Ghassoul clay unit. Part of the silica is of sedimentary origin and is inherited from the siliceous microfossil tests contained within the clay layers. But an important part of the silica probably results from alteration of the Mg-rich clay minerals in the claystones. These are relatively unstable due to the solubility of $\mathrm{Mg}$ in surface waters. Alteration of Mg-minerals by meteoric waters often leads to leaching of $\mathrm{Mg}$ and the in situ preservation of silica which forms a silcrete, such as during weathering of serpentinite (Nickel and Thornber, 1977; Nahon, 1979; Stanger, 1985; Skarpelis, 2006; Lacinska and Styles, 2013). This alteration corresponds to a relative accumulation of the silica derived from the clay minerals according to a mechanism similar to that described in the acidic environments in which silicification was widespread in central Australia (Rayot et al., 1992; Thiry et al., 2006). The tetrahedral rings of the clay mineral structures would favour formation of opal-CT tetrahedral rings by solid state transformation without destroying the entire clay mineral structure. The presence of XRD reflections near $4,45 \AA$, interpreted to indicate residual clay mineral frameworks, is an additional argument for a direct relationship between the claystones and the layered silicifications as a result of "decationization" of the clay minerals.

In this sense, the numerous cracks in the layered silicifications could have resulted from shrinkage due to a loss of volume during the "decationization" of the clay minerals. The silicification of the clay minerals would involve mass loss, particularly $\mathrm{Mg}$ relative to $\mathrm{Si}$, and thus engender shrinkage cracks. This represents a relative accumulation of silica.

Silica deposits within the pores and the cracks must on the other hand be due to silica importation in water and represent absolute accumulations. The precipitation sequence is always from "poorly" crystallized phases (high solubility) towards "better" crystallized phases (which are less soluble and thus more stable).

Recrystallization of the "poorly" crystallized silica phases (opal and pseudo-chalcedonite) is common in the matrix in the layered silicifications and indicates a readjustment in keeping with water flow through the formation. The silica precipitates in pores and cracks tend towards "better" crystallized phases.

\section{Nodular silicifications}

The sequences of crystallisation in the silicified nodules in the dolostones range from cryptocrystalline forms to well developed crystals and indicate a change of composition of incoming solutions during silicification. In order to silicify carbonate material, devoid of clays and quartz, all silica has to be imported. The silica precipitated in pores and voids thus represents the outcome of throughflow of silicabearing solutions. This explains the relations observed between porosity and silicification. The absence of geotropism in the silica deposits, which are arranged in a regular fashion around pores, points to a watersaturated regime.

The silica in solution was acquired from elsewhere, and the most plausible hypothesis is that the alteration of the Mg-rich clay minerals and siliceous microfossil tests in the claystone unit is the source of the silica.

\section{Discussion}

Although the various forms of silicification are different in appearance and arrangement, there are many common characters that relate to the mechanisms and conditions of development.

\section{Origin of the silica and water flow}

All of the silicifications are late with regard to the deposition of the sediments. Those constrained to the clayey horizons may possibly be ascribed to early diagenesis as a result of recrystallization of siliceous microfossils and alteration of smectitic clays. Those in the dolostones are obviously later again because silica infilled fractures could only develop after hardening of the dolostones. Finally, the gogottes, which occur within disintegrated rocks, are absolutely late: they post-date the disruption of the sedimentary layering relating to scarp retreat, and formed in zones near the current outcrop.

The importation of silica implies that significant volumes of silica-bearing solutions have flowed through these formations. This would have required an hydraulic gradient generated by a significant landscepe relief and incisions into the landscape that constituted discharge zones. In addition, microkarstic dissolution of the dolostones to generate porosity into which incoming silica was precipitated can only occur via water flows.

\section{Spatial disposition of the silicified zones}

The connection with the current landscape and morphology in which the Jbel Ghassoul formation occurs is particularly spectacular for the gogotte silicifications. The rounded siliceous lenses are arranged across the superficial disruption structures and disappear quickly, within 10-20 m, beyond the entrances to the underground mining galleries. The layout is similar for the layered silicifications which are 
plentiful and prominent in outcrops of the smectitic clays and yet do not occur in the mine galleries. There is less information about the distribution of the nodular silicifications in the dolostones. However, these are plentiful in the neighbourhood of the layered silicifications but become sparse and eventually disappear higher in the sequence.

The silicified zones are almost exclusively limited to a $10-40 \mathrm{~m}$ wide zone from the edges of outcrops in scarps (Fig. 4). Furthermore, they occur down-dip of the Jbel Ghassoul formation and at the base of scarps. They are absent or very rare up-dip, particularly on the NW side of Jbel Ghassoul fronting the Middle Atlas highlands from which the Jbel is separated by erosion. This distribution of the silicified zones is interpreted to record the locations of outflow of groundwaters that produced the silicification.

\section{Age of the silicifications}

The age of the silicifications is difficult to establish. Nevertheless, our observations lead to the following suggestions.

1) The supply of silica to cracks and pores requires groundwater flows that were only possible after uplift and incision of the Jbel Ghassoul formation in order to create an hydraulic gradient.

This would mean a post-Miocene age as deduced from regional geodynamics (Laville et al., 2007; Babault et al., 2008).

2) The silicifications are above the present day local fluvial base level and relate to the P4-P5 paleopediments (Fig. 2) of the Moulouya system (Lefèvre, 1989). The high pediment abutting the scarps of Jbel Ghassoul is considered to have been a zone of outflow for groundwater perched above the claystone unit. We envisage something like the geomorphology in Figure 18 to provide the hydrological regime that would account for the groundwater source. Correlation of the silicifications with the P4-P5 pediments points to an early to middle Pleistocene age.

3) Linking the silicifications to early to middle Pleistocene paleopediments that display frostshattering features points to cold climates prevailing in the Moroccan mountains and continental basins at the time (Raynal et al., 1986; Lefèvre, 1989; Hughes et al., 2011).

Middle Atlas
Jbel Hariga $1778 \mathrm{~m}$

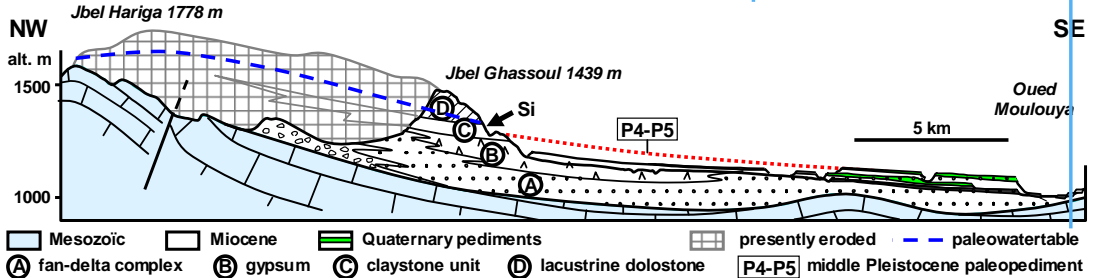

Figure 18 - Suggested reconstruction of P4-P5 landscape to account for the hydrological regime whic generated the groundwater source for the silicification in seepage discharge zones. Disruption of the hydrological regime and loss of the groundwater source would have occurred when incision and erosion separated Jbel Ghassoul from the Middle Atlas.

\section{The mineral sequences}

The variety of silica phases reflects the chemistry of the solutions from which they precipitated (Williams and Credar, 1985). All the silica deposits in pores and cracks show similar mineral successions, starting with crypto-crystalline forms and progressing towards better developed crystals and, ultimately, euhedral quartz. These mineral sequences represent an evolution of the parent solutions from relatively concentrated and enriched in impurity ions towards more diluted solutions with less impurity ions (Thiry and Millot, 1987; Heaney, 1993). But at the same time it is important to recognise that the host rock is also involved in reaction with the incoming groundwaters.

At first, when pores and cracks are not yet coated by silica precipitates, the incoming solutions react and equilibrate with the host rock and progressively leach away cations and anions. In this environment, where there is an abundance of impurity ions, "poorly" crystalline silica will precipitate. As silica deposits increasingly cover the walls of the pores and cracks, the host rock is isolated from the solutions that flow through it, the concentrations of impurity ions are reduced and more highly crystalline silica precipitates (Thiry, 1997; Thiry and Ben Brahim, 1997). So, the changing mineralogical sequence in the pores is also related to a spatial and lateral sequence that develops along the flow path of the groundwater silica solutions (Fig. 19). The incoming solution is expected to have had a composition that was in equilibrium with the final precipitates of silica (euhedral quartz) in the pores, namely that of relatively dilute fresh waters. This explains why the silica deposits develop systematically towards more crystalline and less soluble phases, rather than fluctuate in crystallinity as would be expected if the composition of the incoming solutions directly controlled the nature of the precipitates.

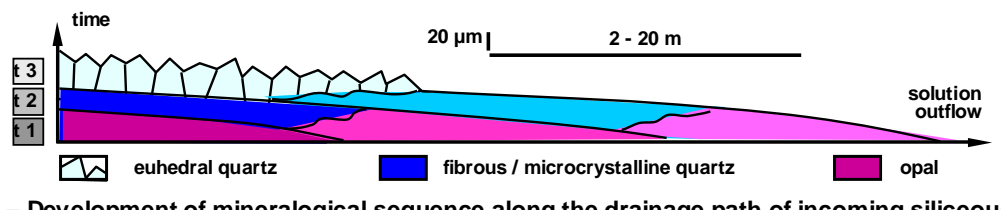

Figure 19 - Development of mineralogical sequence along the drainage path of incoming siliceous groundwater solutions. Contact with the host rock (dolostone or clay) tends to load solutions with impurity ions and thus initiate precipitation of poorly crystallized silica. It is only when incoming solutions are
precipitated.

\section{Geochemistry and precipitation mechanisms}

Silicification as a result of groundwater flow involves three successive mechanisms: (1) Si goes into solution; (2) $\mathrm{Si}$ is transported, and (3) Si solubility is lowered and precipitation is initiated. There is always silica available for solution in sedimentary formations, ranging from the varieties of silica present and/or the alteration of silicate minerals, in particular clay minerals. The groundwaters of temperate regions have silica contents near $15-20 \mathrm{mg} / \mathrm{L}$ in equilibrium with clay minerals common in the aquifers but supersaturated with regard to equilibrium with quartz (Davies, 1964; Hem, 1985).

The precipitation of silica is governed by saturation in relation to the various silica phases. The kinetics of precipitation are slow to very slow compared with those of the other common supergene minerals (for example, gypsum and calcite) (Lasaga, 1995). The precipitation of silica in acutely localized zones, as in gogottes and nodules, implies a strong or sharp gradient of supersaturation imposed by particular local conditions. Three mechanisms can be envisaged.

1) Silica concentration by evaporation of the solution and subsequent precipitation is the "classical" precipitation mechanism called on to explain superficial silicification. This cannot apply to the Jbel Ghassoul situation. Firstly, there would need to have been evaporation of considerable volumes of water to explain the silica mass balance, and this could not have occurred beneath even a limited thickness of rock/soil cover. Secondly, groundwater flowing through the Jbel Ghassoul formation would have been rapidly saturated in calcite and gypsum in preference to silica, which has low dissolution kinetics, and evaporation of such waters would inevitably have led to precipitation of calcite and gypsum, which has not been observed. 
2) Zones of precipitation would correspond to specific environments that "catalyse" the precipitation of silica and/or the crystalline growth of quartz. There is little information about the details of quartz crystallogenesis at low temperature. Speculatively, there may be an important role of some trace elements or specific organic compounds (Mucci et al., 1989; Bennett, 1991; Coddy, 1991). This could occur in the outcrop zone near the point of groundwater discharge. The mixing of groundwater with surface water could initiate precipitation of silica mediated by organic or other compounds, but this must happen without dilution of the incoming solution.

3) Temperature acts in a very significant way on silica solubility (Rimstidt, 1997; Williams et al., 1985). Quartz solubility decreases with the temperature according to an exponential law (Fig. 20): it is more than halved by cooling the solution from 25 to $12.5^{\circ} \mathrm{C}$, and also from 12.5 to $0^{\circ} \mathrm{C}$. These temperatures are in the range that exists between the subsoil and the landsurface in cold climates. Thus, in cold periods, the silica in groundwater may precipitate if the water cools significantly by getting closer to the landsurface. Various forms of silica, including opal, may precipitate along a sharp boundary between cold subsoil and groundwater if cooling is rapid and the supersaturation high.

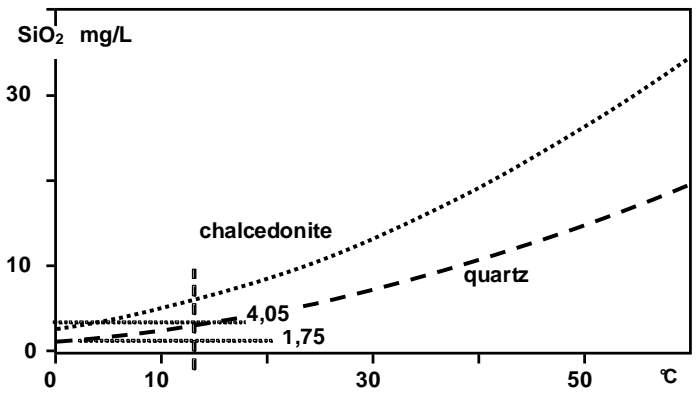

Figure 20-Variations in quartz and chalcedonite solubility with temperature (Bethke, 2002). The solubility of quarl $z$ falls to more than half its value between 12.5 and $0^{\circ} \mathrm{C}$.

Silica precipitation by cooling a solution is the most probable mechanism to explain silicification at or near the point of discharge of groundwaters from the early to middle Pleistocene paleolandscape in the Jbel Ghassoul region. Moreover, this mechanism for silica deposition is completely independent of the nature of the host rock, which is a specific feature of the Jbel Ghassoul silicifications.

\section{Conclusion}

The similarity of silicification phenomena in the various sedimentary facies of the Jbel Ghassoul formation in this location is remarkable and points to specific mechanisms including: (1) importation of silica via groundwater flow, (2) dilute groundwater solutions as evidenced by euhedral quartz crystals forming the final stage of precipitation sequences, (3) precipitation fronts with very strong gradients, and (4) the confinement of silicification to groundwater discharge zones. These silicifications are comparable to groundwater silcretes described in the Paris basin, in Australia and on the Hamada plateaux in Morocco (Thiry and Milnes, 1991; Thiry and Ribet, 1999; Thiry and Ben Brahim, 1997; Thiry, 1999). They imply important water flows to provide the silica and substantial landscape relief to provide an hydraulic gradient that drives the water flows.

The silicification of lacustrine carbonate rocks is generally interpreted to be an indicator of a warm and dry climate (Fersmann, 1926; Kaiser, 1928; Storz, 1928; Radier, 1959; Millot et al., 1959;
Nash etal. 1994). This is also the case for the silicifications that affect the wide calcareous plateaus of the dry landscapes of North Africa (Auzel and Cailleux, 1949; Alimen and Deicha, 1958). However, micromorphological analyses reveal that the silicifications of the Jbel Ghassoul formation are postsedimentary and their geomorphological disposition provides a basis for linking their formation to cold climates of the early to middle Pleistocene. Other silicified materials in the Atlas piedmont (Hamada du Guir) show similar features and have also been interpreted as post-sedimentary silicifications promoted by groundwater flows (Thiry and Ben Brahim, 1997).

These studies show that caution is advisable when assigning a palaeoclimatic interpretation to silicification features. The problem is of broad interest and is not only restricted to the Atlas piedmont formations. In the Paris basin, the silicification of Fontainebleau sandstones, which was assigned to a dry climate (Alimen, 1936), turned out to be connected to groundwater flows under a temperate/cold climate, in landscapes incised during the Quaternary (Thiry et al., 1988). By dating calcite crystals included in the silicified sandstone pans, it has been possible to assign the silicification specifically to the last glacial stages of the Quaternary (Thiry et al., 2013). Similarly, the silicification of lacustrine carbonate rocks in the Paris basin that had been interpreted previously as synsedimentary and concomitant with deposition turned out to be related to groundwater outflows following uplift of the sequence (Thiry and Ribet, 1999). Such silicifications due to near-surface groundwater cooling is suspected for many silicification features in Tertiary sequences, and even in older outcropping formations (such as Cretaceous sandstones) that experienced periglacial conditions during Pleistocene times in France and elsewhere in Europe and North America. Cold stages are major factors in shaping landscapes in Europe and North America and thus silicifications here may be markers of landscape incision.

On the other hand, the case is very different for siliceous duricrusts with pedological characters (illuviation features, geotropic profile) that are well described from Australia and the Paris basin (Thiry, 1999; Thiry et al., 2006). These were formed during warm palaeoclimates with contrasted wet and dry seasons. Silicifications formed via acidification of the groundwater (sulphide oxidation and ferrolysis) are another type, but correspond to climates with low rainfall (Thiry et al., 1995; Thiry et al., 2006)

In all cases, the documentation and interpretation of micromorphological features in relation to field occurrences of silicified materials is crucial and provides the key to unravelling their origin and environment of formation.

Acknowledgments: Research on Jbel Ghassoul formation and field surveys were funded by the Moroccan Centre National pour la Recherche Scientifique et Technique (CNRST) and the University Mohammed Premier in Oujda (program PROTARS III-D15/61). MT and MBB thank the Société du Ghassoul \& ses dérivés SEFRIOUI SARL for access to the mine site and warm hospitality to the former railway station of Tamdafelt. The authors wish also to thank an anonymous reviewer and Dr Philip Hughes, Subject Editor, whose comments helped considerably to improve the focus of the paper.

\section{References}

Alimen H., 1936, Etude sur le Stampien du Bassin de Paris. Mém. Soc. géol. Fr., 31, 309 p. Alimen H., Deicha G., 1958, Observations pétrographiques sur les meulières pliocènes. Bull. Soc. géol. Fr., (6), 8, p. 77-90.

Arbey F., 1980, Les formes de la silice et l'identification des évaporites dans les formations silicifiées. Bull. Centre Rech. Pau. SNPA, 4, 1, p. 309-365.

Auzel M., Cailleux A., 1949, Silicifications nord-sahariennes. Bull. Soc. géol. Fr., (5), 19, p. 553-559. 
Awad H., 1963. Some aspects of the geomorphology of Morocco related to the Quaternary climate. The Geographical Journal, 129(2), p. 129-139.

Babault J., Teixell A., Arboleya M.L., Charroud M., 2008. A late Cenozoic age for long-wavelength surface uplift of the Atlas Mountains of Morocco. Terra Nova, 20, p.102-107.

Beauchamp, W., Barazangi, M., Demnati, A., El Alji, M., 1996, Intracontinental rifting and inversion : Missour Basin and Atlas Mountains, Morocco. AAPG Bulletin, 80, p. 1459-1482.

Benammi M., Jaeger J.J., 1995, Datation des formations continentales du Jbel Rhassoul à l'aide de micromammifères. Notes et Mém. Soc. géol. Maroc, 155, p. 29-77.

Bennett, P.C., 1991. Quartz dissolution in organic-rich aqueous systems. Geochimica et Cosmochimica Acta, 55, 1782-1797.

Bethke, C.M., 2002. The geochemist's workbench release 4.0: a user's guide to Rxn, Act2, Tact, React, and Gtplot. University of Illinois, Urbana, IL.

Bosbach D., Hochella M.F. Jr., 1996, Gypsum growth in the presence of growth inhibitors; a scanning force microscopy study. In: Chemical and biological control on mineral growth and dissolution kinetics, Stillings L.L., ed., Chemical Geology. 132/1-4, p. 227-236

Chahi, A., Duringer, P., Ais, M., Bouabdelli, M., Gauthier-Lafaye, F., Fritz, B., Diagenetic transformation of dolomite into stevensite in lacustrine sediments from Jbel Rhassoul, Morocco. J. Sedim. Res., 69, p. 1123-1135.

Choubert G., 1946, Note préliminaire sur le Pontien au Maroc (essai de synthèse orogénique du Maroc Atlasique). Bull. Soc. géol. Fr., (5), 15, p. 683-691.

Cody R.D., 1991. Organo-crystalline interactions in evaporite systems: the effects of crystallization inhibition. J. Sedimentary Petrology, 61/5, p. 704-718.

Couvreur G., 1966. Les formations périglaciaires du Haut Atlas central marocain. Revue de géographie du Maroc, 10, p. 47-50

Couvreur G., 1981. Essai sur l'évolution morphologique du haut-Atlas central calcaire. Thèse, Lille, 877

Couvreur G., 1988. Essai sur l'évolution morphologique du Haut Atlas central calcaire (Maroc). Notes et Mémoires du Service géologique du Maroc, 318, $391 \mathrm{p}$.

Davies S.N., 1964, Silica in streams and groundwater. Amer. J. Sci., 262, p. 870-890.

Dresch J., Raynal R., 1953. Les formes glaciaires et périglaciaires dans le Moyen Atlas. C.R. sommaire des Scéances de la Société géologique de France, p. 195-197.

Duringer P., Ais M., Chahi A., 1995, Contexte géodynamique et milieu de dépôt du gisement de stevensite (rhassoul) miocène du Maroc: environnement lacustre ou évaporitique ? Bull. Soc. géol. Fr., 166/2, p. 169-179.

Fersmann A., 1926, Über die Eerscheinung der Silizierung in der Mittelasiatischen Wüste Karakum. C.R. Acad. Sci. U.R.S.S., p. 145.

Flörke O.W., Flörke U., Giese U., 1984, Moganite. A new microcrystalline Silica-Mineral. Neues Jahrbachuch für Mineralogie, Abh., 149, 3, p. 325-336.

Frizon de Lamotte D. F., Leturmy P., Missenard Y., Khomsi S., Ruiz G., Saddiqi O., Guillocheau F., Michard A., 2009, Mesozoic and Cenozoic vertical movements in the Atlas system (Algeria, Morocco, Tunisia): an overview. Tectonophysics, 475(1), p. 9-28.

Gomez F., Barazangi M., Bensaid M., 1996. Active tectonism in the intracontinental Middle Atlas Mountains of Morocco: synchronous crustal shortening and extension. Journal of the Geological Society, 153(3), p. 389-402.

Heaney P.J., 1993, A proposed mechanism for the growth of chalcedony. Contrib. Min. Petrol., 11, p. 66-

Hem J.D. 1985, Study and interpretation of chemical characteristics of natural water. 3rd ed. U.S. Geol. Survey Water-Supply Paper 2254, U.S. Govt. Printing Office, Washington, D.C., 263 p.

Hughes P.D., Fenton C.R. Gibbard P.L., 2011. Quaternary glaciations of the Atlas Mountains, North Africa. In: Ehlers, J., Gibbard, P.L. and Hughes, P.D. (Eds) Quaternary Glaciations - Extent and Chronology, Part IV - A Closer Look. Amsterdam: Elsevier. p. 1071-1080.

Hughes P.D., Gibbard P.L., Woodward J.C., 2004. Quaternary glaciation in the Atlas Mountains, Nort Africa. In: Ehlers, J. and Gibbard, P.L. (eds) Quaternary Glaciation - Extent and Chronology. Volume 3: Asia, Latin America, Africa, Australia, Antarctica. Elsevier: Amsterdam. p. 255-260.
Hughes P.D., Woodward J.C., Gibbard P.L., 2007. Middle Pleistocene cold stage climates in the Mediterranean: New evidence from the glacial record. Earth and Planetary Science Letters, 253, p

Kaiser E., 1928, Die Diamanten Wüste Sud West Afrikas. Band I. Dietrich Reiner (Ernst Vohsen) Berlin, $321 \mathrm{p}$.

Lapparent (de) J., 1936, Les milieux générateurs de la montmorillonite et de la sepiolite. C.R. Acad. Sci., Paris, 203, p. 553-555.

Lasaga A.C., 1995, Fundamental approaches in describing mineral dissolution and precipitation rates in: White A.F. \& Brantley S.L., eds, Chemical weathering rates of silicate minerals. Rev. in Mineralogy, 31, p. 23-81.

Laville E., Delcaillau B., Charroud M., Dugue O., Aït Brahim L., Cattaneo G., Deluca P., Bouazza A., 2007, The Plio-Pleistocene evolution of the Souhern Middle Atlas Front Zone (SMAFZ) front of Morocco. Int. J. Earth Sci (Geol Rundsch), 96(2), p. 497-575.

Lefèvre D., 1989, Formations continentales pleistocènes et paléoenvironnements sédimentaires dans le bassin de Ksabi (Moyenne Moulouya, Maroc). Bulletin de l'Association française pour l'étude du Quaternaire, 26/2, p. 101-113.

Lefèvre D., 2008, De la Moulouya à la Mamore. Réflexions sur la stratigraphie du Quaternaire continental du Maroc. Conceptes, attitudes et méthodes. In: H. Aouraghe, H. Haddoumi, K. El Hammouti, eds, Actes de la quatrième rencontre des quaternaristes marocains (RQM4), Oujda 117 nove 2007. vol. 1, Géologie, Paléoenvironnements et Datations, Publications de la faculté des sciences d'Oujda, vol. 1, p. 1-22.

Lefèvre D., Raynal J.-P., Texier J.-P., 1985, De la fin du Villafranchien au début du Soltanien: exemples d'évolution des paléoenvironnements du Maroc occidental et oriental. Colloque "Héritages géomorphologiques et paléoenvironnements du Quaternaire moyen méditerranéen" (Paris, 16/09/85), Association des Géographes Français, p. 1-20.

Martin J., 1981, Le Moyen Atlas central. Etude géomorphologique. Notes et Mémoires du Service géologique, $\mathrm{n}^{\circ} 258$ and 258bis, Service géologique du Maroc, 445p.

McBride E.F., Folk R.L., 1977, The Caballos Novaculite revisited. Part II: Chert and shale members an synthesis. J. Sedimentary Petrology, 47/3, p. 1261-1286.

Medina F., Cherkaoui T., 1991. Focal mechanisms of the Atlas earthquakes, and tectonic implications. Geologische Rundschau, 80, 639-648.

Merino E., Wang Y., Deloule E., 1994, Genesis of banded, fibrous, and twisted quartz by "catalysis", unstable crystallization fronts, and substitution: self-organization in agates. Mineralogical Magazine, 58A, p. 597-598.

Messerli B. Winiger M. 1992. Climate, Environmental Change, and Resources of the African Mountain from the Mediterranean to the Equator. Mountain Research and Development, 12(4), p. 315-336.

Millot G., Radier H., Muller-Feuga R., Defossez M., Wey R., 1959, Sur la géochimie de la silice et les silicifications sahariennes. Bull. Serv. Carte Géol. Als. Lor., 12, 2, p. 3-15.

Mucci A., Canuel R., Zhong S., 1989. The solubility of calcite and aragonite in sulfate-free seawater and the seeded growth kinetics and composition of the precipitates at $25^{\circ} \mathrm{C}$. Chemical Geology, 74, p. 309-320

Nash D.J., Thomas D.S.G., Shaw P.A., 1994, Siliceous duricrusts as palaeoclimatic indicators: evidence from the Kalahari desert of Botswana. Palaeogeography, Palaeoclimatology, Palaeoecology, 112, p. 279-295.

Radier H., 1959, Le Précambrien saharien au Sud de l'Adrar des Iforas. Le bassin crétacé et tertiaire de Gao. Contribution à létude géologique du Soudan oriental.

Raynal R., 1952, Quelques données nouvelles au sujet de l'Oligo-Miocène du bassin de la Moulouya. C.R. somm. Soc. géol. Fr., p. 43-44.

Raynal R., 1961, Plaines et piedmonts du bassin de la Moulouya (Maroc oriental), études géomorphologiques. Inframare, Rabat, $617 \mathrm{p}$

Raynal J.-P., Texier J.-P., Lefèvre D., 1986. Essai de corrélation de l'océan au continent pour le Quaternaire du Maroc. Revue de Geologie Dynamique et de Géographie Physique, 27/2, p. 141147. 
Rayot V., Self P., Thiry M., 1992, Transition of clay minerals to opal-CT during ground-water silicification. In : Mineralogical and geochemical records of paleoweathering, (J.M. Schmitt \& Q. Gall, eds), ENSMP Mém. Sc. de la Terre, 18, p. 47-59.

Rimstidt, J.D., 1997. Quartz solubility at low temperatures. Geochimica et Cosmochimica Acta, 61(13), $2553-2558$.

Rhouta, B., Kaddami, H., Elbarqy, J., Amjoud, M., Daoudi, L., Maury, F., Senocq, F., Maazouz, A., Gerard, J. F. (2008). Elucidating the crystal-chemistry of Jbel Rhassoul stevensite (Morocco) by advanced analytical techniques. Clay minerals, 43(3), 393-403.

Sébrier M., Siame L., El Mostafa Z., Winter T., Missenard Y., Leturmy P., 2006. Active teconics in the Moroccan High Atlas. C.R. Géosciences, 338/1, p. 65-79.

Storz M., 1928, Die sekundären authigenen Kieselsöuren in ihrer petrogenetisch-geologischen Bedeutung. Monogr. z. Geologie und Pal., Ser. II, Heft 4, 481 p.

Takahashi Y., Imai H., Hosaka M., Kawasaki M., Sunagawa I., 2004, Epitaxial lateral overgrowth (ELO): the mechanism of formation of spectre, skeletal, cathedral and related quartz morphologies European J. Mineralogy, 16/1, p. 1009-1017.

Termier H., Dubar G., 1940, Notice explicative de la carte géologique provisoire du Moyen Atlas septentrional au 1/200 000 : notice explicative. Notes et Mém. Serv. Mines Maroc, 24 bis, 74 p.

Thiry M., 1997, Continental silicifications: A review. in: Soils and Sediments: Mineralogy and Geochemistry, H. Paquet, N. Clauer (eds.), Springer, pp. 191-221.

Thiry M., 1999, Diversity of continental silicifications features: examples from the Cenozoïc deposits in the Paris Basin and neighbouring basement. in : Palaeoweathering, palaeosurfaces and related continental deposits, Thiry M. \& Simon-Coinçon R., eds, Spec. Publs. Int. Ass. Sediment., 27, p.

Thiry M., Ben Brahim M., 1997, Silicification de nappe dans les formations carbonatées tertaires du piedmont atlasique (Hamada du Guir, Maroc). Geodinamica Acta, 10/1, p. 12-29.

Thiry M., Bertrand-Ayrault M., Grisoni J.C., 1988, Ground-water silicification and leaching in sands : example of Fontainebleau Sand (Oligocène) in the Paris Basin. Geol. Soc. of America Bull., 100, p. $1283-1290$.

Thiry M., Millot G., 1987, Mineralogical forms of silica and their sequence of formation in silcretes. Journal of Sedimentary Petrology, 57, 2, p. 343-352.

Thiry M., Milnes A.R., 1991, Pedogenic and groundwater silcretes at Stuart Creek Opal Fields, South Australia. Jour. Sediment. Petrol., 61/1, p. 111-127.

Thiry M., Milnes A.R., Rayot V., Simon-Coinçon R., 2006, Interpretation of palaeoweathering features and successive silicifications in the Tertiary regolith of Inland Australia. Journal of the Geological 23-736.

Thiry M., Ribet I., 1999, Groundwater silicifications in Paris Basin limestones: fabrics, mechanisms, and modelling. Jour. Sedimentary Petrology, 69/1, p. 171-183.

Thiry M., Schmitt J.-M., Innocent C., Cojan I., 2013, Sables et Grès de Fontainebleau : que reste-t-il des faciès sédimentaires initiaux? 14ème Congrès Français de Sédimentologie, Paris 2013, Trois excursions géologiques en région parisienne, Livre d'excursions, Publ. ASF, n 74, p. 37-90.

Thiry M., Schmitt J.M., Rayot V., Milnes A.R., 1995, Géochimie des altérations des profils blanchis du régolithe tertiaire de l'intérieur de l'Australie. C. R. Acad. Sci. Paris, 320/II a, p. 279-295.

Trauth N., 1977, Argiles évaporitiques dans la sédimentation carbonatée continentale et épicontinentale tertiaire. Bassin de Paris, de Mormoiron et de Salinelles (France). Jbel Ghassoul (Maroc). Sci. Géol. Mém., 49, 195 p.

Williams, R., Crerar, D.A., 1985. Silica diagenis. II General mechanism. Journal of Sedimentary Petrology, 55(3), 312-321

Williams, R., Parks, G.A., Crerar, D.A., 1985. Silica diagenesis. I. Solubility controls. Journal of Sedimentary Petrology, 55(3), 301-311. 